\title{
O SUCESSO DA TECNOLOGIA BANCÁRIA BRASILEIRA
}

\author{
Por Marcos Bader
}

Doutor em Psicologia pela Faculdade de Filosofia, Ciências e Letras, Universidade de São Paulo e em Engenharia de Produção pela Escola Politécnica, Universidade de São Paulo e Diretor-geral do Bradesco Cartões - São Paulo - SP, Brasil

4025.bader@bradesco.com.br

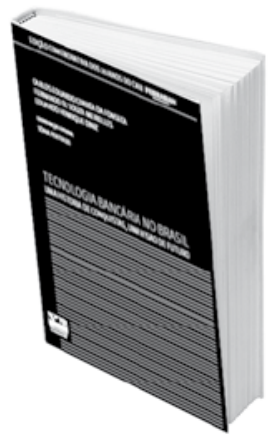

TECNOLOGIA BANCÁRIA NO BRASIL: UMA HISTÓRIA DE CONQUISTAS, UMA VISÃO DE FUTURO.

De Carlos Eduardo Corrêa da Fonseca, Fernando de Souza Meireles e Eduardo Diniz. São Paulo: FGV/RAE, 2010. 420 p.
É impossível dissociar o sucesso do sistema financeiro brasileiro de um de seus principais alicerces: a tecnologia bancária. O constante aprimoramento dos serviços bancários no país, promovidos ao longo de quase cinco décadas, possibilitou às instituições desse setor oferecer a praticamente todos os segmentos sociais da população brasileira seus serviços. A tecnologia bancária brasileira é na atualidade referência mundial, e a economia do país também se serve desse status como alavanca para a sua pujança e reconhecido destaque internacional, uma vez que o alcance das inovações e o crescimento da indústria transcendem o contexto bancário.

Contudo, a evolução da tecnologia bancária brasileira carecia de registros oficiais, uma vez que permanecia restrita aos personagens que protagonizaram essa história. Relatar esse período é o maior mérito do livro Tecnologia bancária no Brasil: uma história de conquistas, uma visão de futuro, obra pioneira no segmento, que documenta a evolução da tecnologia bancária no Brasil, identificando os fatores-chave de seu sucesso e oferecendo ao leitor um conteúdo rico em informações e fatos.

O livro cobre cinco décadas de automação bancária, iniciada na década de 1960, por meio de depoimentos exclusivos de 59 executivos que fizeram parte dessa história. Os capítulos apresentam interessante estruturação que busca agrupar os importantes eventos da evolução da tecnologia bancária nacional, seus atores e situações de grandes impactos e mudanças de paradigma.

A obra foi dividida em 12 capítulos, quatro associados a períodos cronológicos desse processo e seis envolvendo temas relacionados à automação bancária. Ao final de cada capítulo, o leitor ainda tem acesso a um resumo analítico, com mais informações e uma rica contextualização sobre cada período analisado. Os autores dedicam a parte final do livro à discussão do futuro da tecnologia bancária, avançando o debate e, ao mesmo tempo, propondo novos rumos para automação bancária brasileira.

Os depoimentos dos profissionais dessa saga foram coletados em dez mesas-redondas conduzidas na sede da FGV-EAESP, cada uma delas associada a um capítulo do livro. Esse importante resgate histórico teve a coordenação editorial da jornalista Sônia Penteado. O livro foi lançado durante o Ciab Febraban 2010 - Congresso Internacional de Automação Bancária - como parte da comemoração dos 20 anos do Ciab. Além da versão impressa, a obra conta com um website (www. automacaobancaria.com.br) com os vídeos das mesas-redondas, e a possibilidade enviar comentários.

Conforme salientado no prefácio por Carlos Eduardo Corrêa da Fon- 
seca (o "Karman"), que foi superintendente da Itautec e diretor executivo de TI do Banco Real ABN Amro, as grandes transformações advindas da automação bancária contribuíram para a seleção dos temas e o convite aos executivos, cujos depoimentos foram registrados no livro. Este contou ainda com o auxílio dos professores Fernando de Souza Meirelles e Eduardo Diniz , ambos da FGV-EAESP. O primeiro assumiu a coordenação das mesas-redondas e produziu uma análise da evolução dos gastos em TI no setor. O segundo teve como tarefa a sumarização dos depoimentos, identificando os catalisadores de inovação em cada um dos períodos analisados.

O capítulo inicial descreve a mudança pela qual passaram as instituições financeiras com a instalação dos computadores a fim de agilizar o processamento de dados e o ambiente de retaguarda. É nesse período que os grandes bancos passam a contratar engenheiros, complementando as atividades de advogados e contadores, que tradicionalmente dominavam a força de trabalho do setor bancário.

As lideranças dos dois maiores bancos privados no país - Bradesco e Itaú, com Amador Aguiar e Olavo Setúbal, respectivamente - são consideradas os principais catalisadores no início desse processo de automação. O Bradesco, líder entre os bancos privados, decorrente da mudança radical na forma de trabalho dos bancos, transformou as sisudas e imponentes agências em instituições voltadas à prestação de serviços, com ambientes mais espaçosos, e foco nas áreas de atendimento e conveniência aos clientes. O Itaú, chamado na época de "Banco dos Engenheiros", privilegiava o uso do computador para a racionalização dos sistemas, a normatização dos processos e a eficácia dos controles financeiros e contábeis.
$\mathrm{Na}$ Introdução do livro, Meirelles enfatiza que esse início possibilitou a evolução dos sistemas paralelos para o Listão e slips de saldos, a entrada de dados via cartões e fitas magnéticas, a padronização dos cheques, a introdução do CMC-7, a padronização dos boletos de cobrança, o início da troca de arquivos em fitas magnéticas, as primeiras experiências de transmissão de dados e os subcentros de entrada de dados.

Os momentos cruciais de questionamento e oportunidades que surgiram durante as décadas de 1970 a 1980 são analisados no terceiro capítulo. Os depoimentos mostram que, de forma visionária e inteligente, esse período controverso impulsionou a criação e a consolidação da indústria nacional de hardware e software, além de centros de excelência para a formação de recursos qualificados apresentados no capítulo seguinte.

A narrativa envolvente reproduz o dinamismo dos agentes diante de cenários que propiciaram gigantescas revisitações de processos constituídos, tais como as descritas no segundo e no quinto capítulo, como também em situações de destruições criativas, como as apresentadas no oitavo e nono capítulos.

A solidez e modernidade do sistema financeiro nacional encontram amplos motivos de orgulho no sétimo capítulo. Esse é indiscutivelmente um fator de vantagem competitiva que possuímos, resultante da sinergia alcançada pelas diversas frentes de desenvolvimento de nossa tecnologia bancária, alicerçada pela regulamentação do Banco Central.

O décimo capítulo encerra o registro histórico ao descrever a bemsucedida função de incentivo e palco de fomento à inovação desempenhada pelo Cnab (Centro Nacional de Automação Bancária) e pelo Ciab.

O $11^{\circ}$ capítulo foi construído de forma coletiva, adaptando uma metodologia utilizada no Fórum de Inovação, também organizado na FGVEAESP para projetar diferentes visões sobre os rumos da tecnologia bancária no país. Sessenta e seis profissionais com diferentes perfis e experiências participaram desse fórum, entre diretores de tecnologia dos bancos, executivos de empresas fornecedoras de produtos de informática, consultores, professores e doutorandos.

O livro finaliza com o capítulo assinado por Diniz, sintetizando toda a discussão presente na obra e destacando a tecnologia, o mercado e a regulação como importantes componentes ambientais dessa história de sucesso.

Nos últimos anos de mudança de patamares tecnológicos, assistimos ao desenvolvimento da tecnologia bancária nacional, resultado de um conjunto de esforços altamente sinérgicos de um seleto grupo de executivos e empreendedores que compartilharam a visão de um novo sistema bancário, hoje referência mundial, que contribui significativamente para elevar a imagem do Brasil como representante de uma de suas áreas de excelência. E para aqueles que creem que o passado é imprevisível, aqui estamos de volta para o futuro.

Este importante resgate histórico em um país dito "sem memória" pode ainda ser enriquecido com a publicação de imagens e fotos dos equipamentos utilizados nas agências e respectivos layouts, os enormes computadores dos CPDs, os primeiros microcomputadores, as fitas magnéticas e os cartões perfurados. Fica a sugestão para uma próxima empreitada impressa ou a inserção deste interessante material no site do livro. Seria muito impactante a comparação visual dessa evolução tecnológica, principalmente para a geração já acostumada com o acesso aos serviços bancários via web e celular. 